\title{
TALENT MANAGEMENT
}

\author{
T. Kroupa
}

Recived: December 15, 2005

\begin{abstract}
KROUPA, T.: Talent management. Acta univ. agric. et silvic. Mendel. Brun., 2006, LIV, No. 3, pp. 137148

The contribution describes the methodology of work with human assets, and namely talent management representing a system of work with employees having over-average potential and representing the source of competitive advantage for the company. The work introduces methodological tools for implementing the system of talent management in the following fields: defining the talent, identification of talents, creating the conditions, care at the side of management, individual or group related technical education, development by way of key competences and evaluation of results, both regarding the abilities and skills of individuals through key competences, and by way of indicators of working performance. Describes evaluation using key competences minimal, optimal and actual competence profile and the way of describing competences by behavioural scale. The paper is the part of the research grant MSM 6215648904.
\end{abstract}

education, development, talent, talent management, key competence, evaluation

\section{INTRODUCTION}

At he present day most companies highlight the necessity of developing and educating their employees, in other words something that can be also called assets of the company. The knowledge and the skills of the employees can be defined as capital, or intellectual assets of a company. As based upon the definition of intellectual assets (Armstrong, 2002), the enterprise should choose a strategy allowing to sustain its know-how, while developing it and being able to cope with the ever progressing competitive fight in the field of business.

Accordingly, the companies should intensify their efforts in searching for new and talented personnel, along with preparing conditions for their development and fostering their individual and professional growth. There are many companies expending considerable resources for the development and education of their employees, however, it should be always born in mind that the linking of the development to motivation and to compensation should be determined at the onset of the implementation, and all that in compliance with the existing corporate culture.
The idea of investing into human capital was first pronounced by Adam Smith (1776). In his book The Wealth of Nations he maintained that the differences between the fates of individuals having different levels of education and qualification reflect the differences in earnings that have been necessary for covering the cost expended for acquiring such skills. The return on investment into skills, accordingly, can be compared with the return on investment into material assets.

Bontis et al. (1999) have defined human capital roughly as follows: „Human capital represents the human factor in an organisation, exactly the combination of intelligence, skills and experience gives the organisation its special character. The human component part of an organisation are those components that are capable of learning, changing, innovating and exerting creative efforts, and if properly motivated, all that can ensure long-time survival of the given organisation."

In the field of research I deal with problems of talent management, i.e. the issues of identifying and developing chosen employees within the conditions of competitive environment in an international scale. 
The objective of my paper is to introduce a methodological framework for the application of talent management under the conditions of an international company, determining the prerequisites for implementing talent management, namely the definition of talents, methods for identifying talents, methods of professional development and education of talents, the utilisation of talents for the development of the company, motivation, career progression and defining the evaluation framework for the profitability of this process.

\section{MATERIAL AND METHODS}

Talent management is a system of approaches and principles of HR work whose detailed implementation depends, in the last instance, upon the given company. The goal, however, is always the same: to make full use of talents (single persons) for the success of the company. The primary task of talent management is to recognize ,a talent" among the employees and to create conditions for his/her development (Fig. 1).

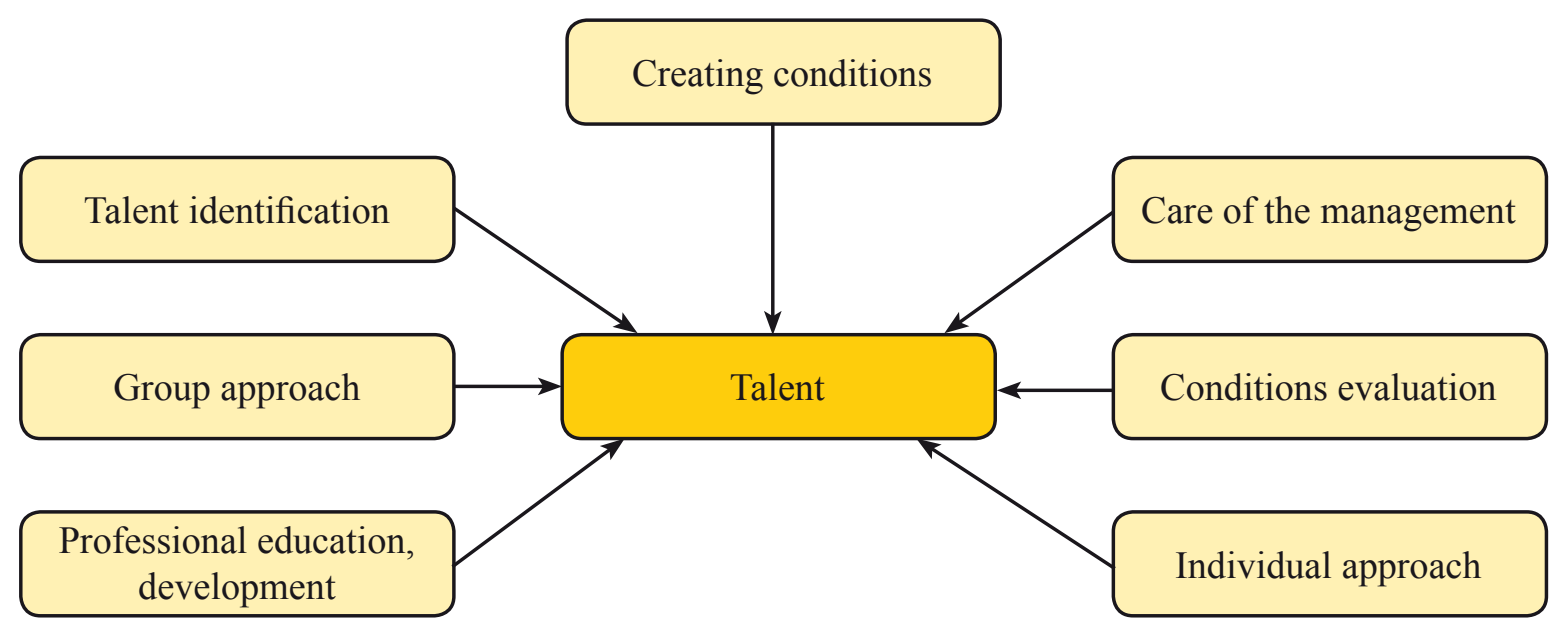

1: Talent management model

\section{Definition of talents}

The definition of talent may vary among the companies, but generally it can be stated that they are usually young employees under thirty years of age with above-average development potential in certain fields. These fields can be classified in two groups, namely the field of knowledge depending upon the scope of business of the given company (hard skills) and the field of abilities and skills (soft skills).

\section{Talent identification}

Each company should define a general profile of job or working position that should be met by each employee in the respective position. This profile should specify the basic characteristic requirements for performing the function: achieved education level, professional prerequisites, specialised knowledge, language skills.

In addition to that the competence profile should be specified (Kubeš, 2004), in other words the fundamental prerequisite relating to abilities and capabilities, or the key competence for performing the given function. A talent in general is a person whose evaluation outcome, both in the general and the competence profile, exceed the specified optimum profile for the given position.

\section{Main criteria for talent selection}

\section{Evaluation of the achieved level of key competence}

The management of competence is an approach to managing companies founded upon a harmonious development of ,hard and soft” business aspects, where the world of objectives and requirements, on the one hand side, and the world of human resources and further preconditions for achieving desirable output, on the other side, meet in a relationship of synergy. The competences are competences of people working for the company. Competence is perceived as the sum of achieved performance (human labour) and the input of potential (or human resources). A company that does not develop its possibilities in the long term can not reach the required results over a longer period, as well as the required performance, in the long run, can not be achieved by a person without developing his/her resources (Plamínek, 2005).

Human resources comprise types of resources (Fig. 2) that can not change or that are not efficient from the viewpoint of the management (what people want and what they believe) and human capabilities (what they know and what they are able to do). The characteristics are important for the work with talents, and in the course of acquisition of people for the company it makes no sense to change them. The remai- 
ning two categories, however, can be often changed within a broad range. Approaches can originate, develop and weaken, they can disappear under the influen- ce of a manager (being loyal to the company, to the corporate idea). Similarly, the capacities can be efficiently modified and developed by education.

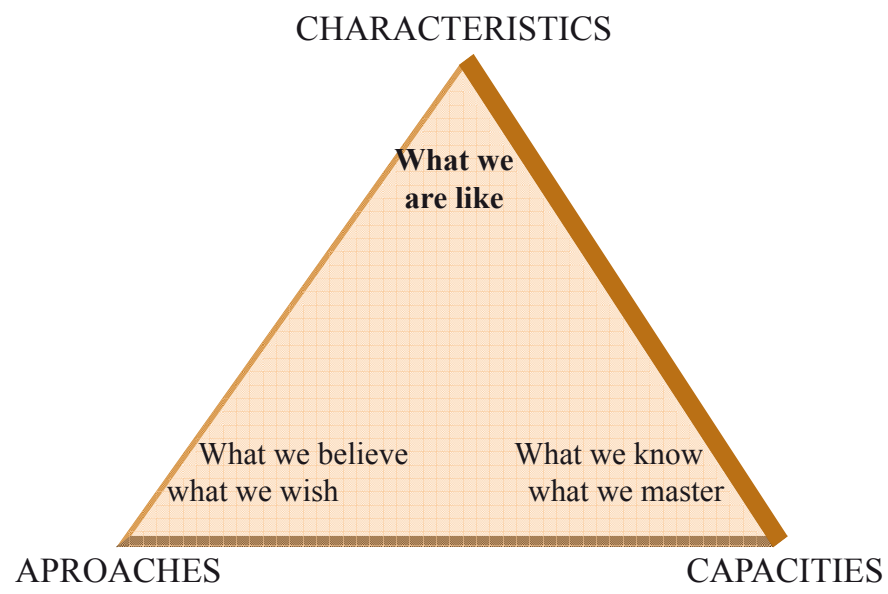

\section{2: Triangle of human resources (Plamínek, 2005)}

For the purpose of assessing the competences a minimum competence profile should be determined, i.e. the minimum level of key competences for performing a certain function, but also the best or optimum competence profile should be set, i.e. such level of key competences for the given function that ought to be achieved by the employee after having acquired experience in this position.

If, during regular periodical evaluation of key competences (Tab. III) an employee in the given position has been identified whose key competence level exceeds the set optimum profile for the position held, we have identified an employee who can be classified for the talent management program.

\section{Regular evaluation of working performance}

The company is expected to adjust the system for the evaluation of working performance according to concrete and clearly defined indicators for the assessment of the working performance as a component part of a comprehensive evaluation system of employees. Then, on the basis of fulfilling or exceeding these indicators a talent can be identified for the integration of the employee into the talent management program. Another function of the regular evaluation of working performance is the continuous assessment of how the indicators are met, depending upon the gradual education and development as well as measuring the effect of the educational process upon the working performance and the respective indicators.

\section{Auxiliary criteria for talent selection}

Evaluation of the results of educatory projects

Provided the company has an adjusted system of education and development of employees allowing to assess the results of the development and training clearly and by way of measurable factors, or possibly in a form of an assessment and development centre, based upon evaluation criteria set in advance, then it is possible to describe a positive change concerning behaviour, knowledge, and skills of an employee in the course of time. If the level of change exceeds the average, we can again identify a talent and classify the employee for the talent management program.

\section{Results of assessment centre / development centre}

If the company carries out HR audit by way of $\mathrm{AC} /$ DC (Hroník, 2002) for various purposes or also for the identification of talents, we can select employees, according to testing levels and criteria determined in advance, who can be classified for the talent management program.

\section{Career interview}

A career interview as such is an indivisible component part of the talent identification process, as it serves for comprehensive diagnostics of the employees from the viewpoint of their motivation and personality profile.

Follow-up testing can serve to obtain personality characteristics, the characteristics of a working role and intelligence, which helps to identify whether the prerequisites for the classification of the respective employee for embarking in the talent development project are fulfilled or not.

As a rule, it is necessary to combine a career interview with one of the above methods, but the career interview with the employee is a must. 


\section{Creating conditions for talent development}

Description of a starting situation in the company, specification of the company, long term development strategies

The company defines and describes the existing situation in the field of HR management: the methods of development, education, evaluation and motivation of the employees. The present day strategy of the company in the field of its business should be described as well as its long-term strategy from which the new and optimised strategy in HR management should be reeled off.

\section{Adjusting the system of work with intellectual assets}

The proper functioning of the company needs the definition of the principle of working with intellectual assets. The latter can be divided into three parts: human capital, company capital and organisational capital (Armstrong, 2002). Human capital can be understood as the knowledge, the skills and the abilities of the employees of the organisation. The company capital can be understood as inventories and knowledge flow inside and outside of the organisation, whereas the organisational capital can be understood as institutionalised knowledge owned by the organisation. This allows to deduce that the proper functioning of a company needs to work out and describe a system of work with each of the component parts of intellectual assets, so as to ensure the development of human capital. The following control of knowledge should enhance the development of the company assets and lead to the development of the organisational capital by information exchange. All three component parts contribute to the development of the company.

\section{Setting the targets for the participants and the company}

In general the targets of the participants can be defined as motivation and development (personal, professional, managerial) with the support of the company management. The goals of the company can be seen in finding new approach to problem solution - creative solutions, strengthening of the competitive edge of the company, identification of the employees with the potential of managerial abilities and skills (succession plan).

\section{Description of optimum target state}

As based upon the strategy of work with intellectual assets, the company should specify the desirable target condition that it wishes to achieve for being able to evaluate the ongoing process of talent management as well as to measure the effectiveness of allotted means. In general it is valid that time and funds invested into motivated and talented people will bring return in the course of time, nevertheless it is also necessary to monitor and to measure quantitative or qualitative indicators specified in advance, and namely for assessing whether the resources invested into education and development have been used efficiently.

\section{Creating the conditions, the support and development of talents}

There are various options for creating suitable conditions for assisting a talent, but the key way consists in offering room and responsibility to the talent, even for the price that I may take a risk as manager. Diversified methods can be used for developing talents, possibly also combinations of the following methods: integrating the talented people into projects where they can show their potential, systemic and regular evaluation of the employees ' potential by the managers, application of an internal or external diagnostic program for the identification of talents and preparation of a suitable development model.

The development of a group of talents differs from the development of other groups of the so.-called „intellectual assets“ of a company (high performers employees, mentors, coaches etc.). People in a group of talents usually lack standard working, managerial and communication habits including experience, but on the other hand the communication within the company can derive an advantage from offering more room exactly to those who do not suffer from ,operation blindness".

Learning by experience is the most expensive way of development due to the fact that experience tends to bring also errors and failures. Accordingly, the development of talents requires special programs to be developed with the basic target of quickly developing the necessary habits in a motivating way, without stifling their natural creativity. That is why the systems of creative workshops are indivisible parts of such development programs. On the one hand side they help to make use of the group potential (ideas of how to solve real problems of the company), and on the other hand they are highly motivating for the participants by offering them assistance and the possibility of self-expression. The development program of talents should be carried out in close co-operation with their managers, which is the only way of highly accelerated development, since the employees can see the direct impact of education and development upon their work.

\section{Organisation of development and talent education}

The training program should comprise two basic fields. The one are the co-called soft skills, or the field of abilities and skills, whereas the second group are 
the so-called hard skills, namely the knowledge of the employee including that of corporate know-how.

The soft skills should include modules or parts developing the abilities and skills in the following fields. The first module focuses upon learning one's ego, or self reflection, then comes the module of the identification of an individual in the relationship to a colleague and the team - this is teamwork, development and co-operation within a team, with team dynamics, the task or role of an individual in a team. Further modules follow focussing upon managerial prerequisites and management skills. The next step after the management skills is a training focussing upon team leadership, the field of work with the ideas of others and the ethics of a manager of an individual and of a company.

Regarding hard skills, it is desirable to combine two approaches: the individual approach and the group approach. For the purpose of developing talents it is important to rely upon the support of company management, and namely not just in that the management decides upon and supports the development of talented employees, but it should also play an active role (Tab. I). The individual approach is seen predominantly in the field of mentoring and coaching of each talent identified by the manager. Another positi- vely accepted component part of individual approach is an information database, to be studied by e-learning, using all sorts of interactive forms. However, the development and education by way of individual forms has certain limits; that is why the individual approach should be complemented by group-type approach covering various group seminars, trainings and workshops.

\section{Methods of care for talents at the side of the management}

Any HR work requires the support by the management of the company. As mentioned above, the company deals with the fields of goals and human resources, and the work with human resources is indispensable for achieving the goals. There are many forms of education in the company, but educating talents has high priority, being oriented to long-term development of HR in a company.

It is obvious, accordingly, that a clear and transparent support provided by the management for the development of talents is needed, and at the same time also the specification of goals and strategies that are in the focus of the management. Talent management uses diversified methods (Tab. I).

I: Methods of talent development

\begin{tabular}{|c|c|c|}
\hline Role & Target & Recipient \\
\hline Lector & to provide knowledge and teach new skills & $\begin{array}{l}\text { group of employees having common } \\
\text { orientation or solving the same set of } \\
\text { problems }\end{array}$ \\
\hline Trainer & $\begin{array}{l}\text { to train procedures determined in advance } \\
\text { and strengthen the skills }\end{array}$ & $\begin{array}{l}\text { group of employees who will apply the } \\
\text { procedure }\end{array}$ \\
\hline Instructor & to offer specific technical procedures & $\begin{array}{l}\text { a group or an individual employee using a } \\
\text { new tool }\end{array}$ \\
\hline Tutor & $\begin{array}{l}\text { to offer support and information based upon } \\
\text { own experience }\end{array}$ & usually a group of new employees \\
\hline Mentor & to hand over experience and offer assistance & mostly a new employee \\
\hline Couch & $\begin{array}{l}\text { to focus the attention of the trainee upon the } \\
\text { substance of the problem, enabling his/her } \\
\text { full use of intrinsic capacities }\end{array}$ & $\begin{array}{l}\text { an employee in a new or difficult situation } \\
\text { preparing for a new position, or an employee } \\
\text { in a specific position without any chance of } \\
\text { using standard development activities }\end{array}$ \\
\hline
\end{tabular}

Corporate experience relating to development and education highlight in particular the activities that are grounded in reality, not just model situation. They are based upon the fact that all who are included in the development of talents have already met the requirements concerning the level of knowledge according to the admission criteria. The aim resides in the development of abilities and skills and - as based upon practical experience - the coaching sets in, as a most suitable method for releasing the potential of persons who have been selected as talents (Tab. II). 
II: Matrix of the talent development method

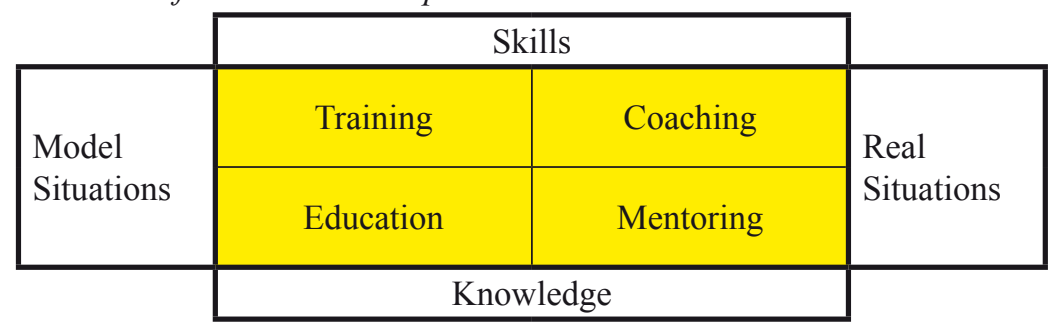

\section{Evaluation of the program}

Human resources in general can become exhausted, but they can also renew and develop. On the other hand the abilities (knowledge, and skills) do not diminish or get exhausted by repeated use, but they develop. Measuring human resources differs from measuring performance in many aspects. Performance is measurable at the output of activities, whereas human resources are a certain potential that should be available, that should be monitored and worked with, although it may not be quite obvious in the performance.

The evaluation of the contribution of talent management can be considered from two viewpoints. The first is the contribution for the organisation, the second the contribution for the individual. However, it should be always recognised that the contribution for the individual be in line with the interests of the organisation.

\section{Plus at the side of the organisation:}

- Source of the competitive advantage of the organisation

- Investment in human assets

- Policy of employment and succession plan

- Development of professionalism concerning individuals and the whole company

- Tool of competition struggle

- Strategy of diversification and differentiation

- Change of thought.

Plus at the side of the employee:

- Personal development

- Motivation

- Self-actualisation of the employee

- Career progression

- Professional growth

- Managerial growth.

In general the evaluation of contributions for both sides in the long-term perspective should be brought in harmony, since we are talking about the key bearers of corporate know-how. The detailed evaluation of the plus for the organisation and its measurement can be described as follows, according to the detailed sys- tem of HR work (the stages comply with the phases of development of HR work in the companies).

\section{HR management without effectiveness evaluation}

This model is current in smaller companies that either lack resources or do not apply enough resources for the development and education of their employees or, considering their market situation, they do not see it as an essential issue. Such organisations have no closely specified target of education, they lack specific indicators allowing to evaluate their return on investment in this field.

\section{Evaluation of the overall return on resources} invested into training, education and development

This model can be seen in larger companies having a specialised department that adjusts the targets in the field of education and development of employees in accordance with the corporate personal strategy.

The company decides about a certain level of resources that it is willing to invest into training, education or development and works with this total amount with the idea of depreciating such investment in achieving an outcome that is at least equal. In practice this should be reflected in the rise of the yields or profit.

\section{Evaluation focussing on individuals}

This model is used in large companies with specialised departments that work with selected employees or groups of employees in a detailed way. The evaluation of the education process per employee is the most detailed one, but also the most demanding variant of assessment in the field of labour education. It is preferred by companies focussing upon knowledge management, and possibly companies following the model of a learning organisation. This model is based upon detailed assessment of employee education and upon a comparison of the effect of education reflected in their working performance.

Let us describe the situation using the example of a group of talents. A corporation invests resources into this targeted and defined group of employees, controlling the effectiveness of educating these groups on 
the basis of the evaluated results. The actual assessment is carried out from two perspectives. The evaluation of individuals from the viewpoint of working performance or accrual of performance on the one hand side, and the evaluation of the individuals as based upon the capacities and skills on the other side - see the assessment of key competences (Tab. III). Both types of evaluation focus, directly or indirectly, upon the evaluation of the contribution brought by HR work.

The contribution of the individual is evaluated in form of the change of working performance due to changed abilities and skills, as well as the change of ability and skills that is due to the education of a group of talents.

This means in practice that we evaluate (upon the basis of achieved measurable results), by way of example, a business representative whose key indicators are profit or yields. In marketing oriented positions the contribution can be evaluated on the basis of measurable contributions of components of marketing and communication mix, whereas in administrative positions the substance can be found in the impact upon reducing internal corporate cost, or possibly knowledge of professional character that is more difficult to measure.

The evaluation of abilities and skills is carried out by assessing the key competence as well as the actual profile in relationship to the minimum and optimum profiles. By way of comparing the actual profile with the minimum profile and the optimum one we find the field of competence that ought to be developed in every and each person. The results serve also as a basis for further determination of individual development plans that are prepared for each individual and implemented within the career interviews.

\section{Results}

The described methodology of talent management shows that there are crucial fields that should be implemented for talent management. The following deserves being cited: clear support of the HR development by the company management, definition of indicators and adjusting the way of evaluating the results of working performance assessment, defining and adjusting the system of continuous evaluation of the key competences.

If HR work is not perceived by the corporate management as a priority, there is a high probability that no talent management may be implemented; if the company perceives HR work as a long-term development strategy, the methodology for talent development is likely to get, ,green light“.

Now as regards the assessment of the results of working performance. On the general level I suppose that every and each corporation evaluates its results, at least the economic ones, and how the evaluation is carried on is only a question of the adjustment of the system. If such evaluation is carried out, then the next step, rather an easy one, is adjusting the assessment to the individual, i.e. Performance Management. Performance management offers detailed information of the individual person serving for assessing the indicators of working performance following the integration in the project of talent development.

The last very important field is the evaluation of key competences. In order that the system can function, the minimum and optimum profiles for groups of positions should be set (Tab. III), and further also the behavioural scales are needed (Tab. IV), namely general expressions for various stages of competence. Also a comprehensive assessment form should be available serving for the periodical assessment of competences. The following form describes competences including the minimum and optimum profile for the position of a business representative. The actual evaluation has two phases: self-assessment of the person to be evaluated (who does not know the minimum and optimum profile), then the evaluation of the person by his/ her superior - who again does not know the minimum and optimum profile; then the assessment interview follows. At the stage of this interview the minimum and optimum profiles are already known and the evaluated person is compared against these profiles. The actual profile also identifies the strong and the weak sides of the individual relating to the different competences. The individual development plans are created upon this basis, and namely as a part of talent management with the goal of strengthening the strong points and eliminating or reducing the weak ones.

A well adjusted system of selecting and educating talents in a company can prevent undesirable de-motivation of the employees with the resulting loss of the intellectual potential of the enterprise. In the course of developing talents a moment occurs when a group of talented people has been defined and we have already invested time and money into them, but we ought to adjust the motivation system so as to make use of such group, to offer these people room for self-actualisation and let them work on projects in positions with long-term perspective and a clear vision of growth. For real talents the deepest motivation is being motivated by work itself, and not even the best compensation can equal the driving force of work that people do enjoy and that is purposeful. 
III: Record of the assessment of key competences of an employee

Evaluation according to the key competence criteria and scoring scale

\begin{tabular}{|c|c|c|c|c|c|c|c|c|c|c|}
\hline \multirow{2}{*}{\begin{tabular}{|l|} 
Evaluation criteria \\
1. Initiative
\end{tabular}} & \multicolumn{5}{|c|}{ Profile } & \multicolumn{5}{|c|}{ Evaluation } \\
\hline & & & & & & & & & & \\
\hline - Bringing proposals and solutions independently & 1 & 2 & 3 & 4 & 5 & 1 & 2 & 3 & 4 & 5 \\
\hline - Overcoming of problems & 1 & 2 & 3 & 4 & 5 & 1 & 2 & 3 & 4 & 5 \\
\hline - Looking for new opportunities and possibilities & 1 & 2 & 3 & 4 & 5 & 1 & 2 & 3 & 4 & 5 \\
\hline - Responsible for his/her own work & 1 & 2 & 3 & 4 & 5 & 1 & 2 & 3 & 4 & 5 \\
\hline - Applying appropriate risk & 1 & 2 & 3 & 4 & 5 & 1 & 2 & 3 & 4 & 5 \\
\hline \multicolumn{11}{|l|}{ 2. Orientation to professionalism, quality of work and target } \\
\hline - High professionalism & 1 & 2 & 3 & 4 & 5 & 1 & 2 & 3 & 4 & 5 \\
\hline - Quality of work result & 1 & 2 & 3 & 4 & 5 & 1 & 2 & 3 & 4 & 5 \\
\hline - Work quality complies with international standards & 1 & 2 & 3 & 4 & 5 & 1 & 2 & 3 & 4 & 5 \\
\hline - Healthy ambitions as basis of work performance & 1 & 2 & 3 & 4 & 5 & 1 & 2 & 3 & 4 & 5 \\
\hline - Only the implemented result is held for working performance & 1 & 2 & 3 & 4 & 5 & 1 & 2 & 3 & 4 & 5 \\
\hline \multicolumn{11}{|l|}{ 3. Customer orientation } \\
\hline - Offering the best solutions and services to customers & 1 & 2 & 3 & 4 & 5 & 1 & 2 & 3 & 4 & 5 \\
\hline - Adapting internal processes to the clients' requirements & 1 & 2 & 3 & 4 & 5 & 1 & 2 & 3 & 4 & 5 \\
\hline - Bearer of the relationship between customer and company & 1 & 2 & 3 & 4 & 5 & 1 & 2 & 3 & 4 & 5 \\
\hline - Continuously analysing the requirements of customers & 1 & 2 & 3 & 4 & 5 & 1 & 2 & 3 & 4 & 5 \\
\hline - Ability to apply suitable methods and styles of dealing with customers & 1 & 2 & 3 & 4 & 5 & 1 & 2 & 3 & 4 & 5 \\
\hline \multicolumn{11}{|l|}{ 4. Organisational abilities, decision making, problem, conflict solving } \\
\hline - Good organisational work and project management & 1 & 2 & 3 & 4 & 5 & 1 & 2 & 3 & 4 & 5 \\
\hline - Ability to decide and to bear personal responsibility & 1 & 2 & 3 & 4 & 5 & 1 & 2 & 3 & 4 & 5 \\
\hline - Ability of qualified analysis and strategic orientation & 1 & 2 & 3 & 4 & 5 & 1 & 2 & 3 & 4 & 5 \\
\hline - Ability to solve problems and material conflicts & 1 & 2 & 3 & 4 & 5 & 1 & 2 & 3 & 4 & 5 \\
\hline - Ability of feedback and of assessing work results & 1 & 2 & 3 & 4 & 5 & 1 & 2 & 3 & 4 & 5 \\
\hline \multicolumn{11}{|l|}{ 5. Communication skills } \\
\hline - Communicates clear unambiguous and truthful information & 1 & 2 & 3 & 4 & 5 & 1 & 2 & 3 & 4 & 5 \\
\hline - Information sharing capacity & 1 & 2 & 3 & 4 & 5 & 1 & 2 & 3 & 4 & 5 \\
\hline - Communication skill & 1 & 2 & 3 & 4 & 5 & 1 & 2 & 3 & 4 & 5 \\
\hline - Communication as a prerequisite to learn the customer's wish & 1 & 2 & 3 & 4 & 5 & 1 & 2 & 3 & 4 & 5 \\
\hline - Perception of internal and external communication as one whole & 1 & 2 & 3 & 4 & 5 & 1 & 2 & 3 & 4 & 5 \\
\hline \multicolumn{11}{|l|}{ 6. Team skills } \\
\hline - Preferring and clearly supporting teamwork & 1 & 2 & 3 & 4 & 5 & 1 & 2 & 3 & 4 & 5 \\
\hline $\begin{array}{l}\text { - No restriction on individual performance and responsibility by } \\
\text { teamwork }\end{array}$ & 1 & 2 & 3 & 4 & 5 & 1 & 2 & 3 & 4 & 5 \\
\hline - Achieving synergic effect through teamwork & 1 & 2 & 3 & 4 & 5 & 1 & 2 & 3 & 4 & 5 \\
\hline - Respecting the other team members, using their potential & 1 & 2 & 3 & 4 & 5 & 1 & 2 & 3 & 4 & 5 \\
\hline - Good guess and utilisation of differentiated team roles & 1 & 2 & 3 & 4 & 5 & 1 & 2 & 3 & 4 & 5 \\
\hline \multicolumn{11}{|l|}{ 7. Managing people, motivation, coaching } \\
\hline $\begin{array}{l}\text { - Opening up new possibilities and the ability to acquire the approval of } \\
\text { others }\end{array}$ & 1 & 2 & 3 & 4 & 5 & 1 & 2 & 3 & 4 & 5 \\
\hline - Clearly supports the development and performance of colleagues & 1 & 2 & 3 & 4 & 5 & 1 & 2 & 3 & 4 & 5 \\
\hline - Exerts strong social competence & 1 & 2 & 3 & 4 & 5 & 1 & 2 & 3 & 4 & 5 \\
\hline - Ability to offer feedback & 1 & 2 & 3 & 4 & 5 & 1 & 2 & 3 & 4 & 5 \\
\hline - Ability to convince and influence others & 1 & 2 & 3 & 4 & 5 & 1 & 2 & 3 & 4 & 5 \\
\hline \multicolumn{11}{|l|}{ 8. Presentation, assertivity } \\
\hline - Ability to clearly present his/her ideas and intentions & 1 & 2 & 3 & 4 & 5 & 1 & 2 & 3 & 4 & 5 \\
\hline - High formal level of expression and behaviour & 1 & 2 & 3 & 4 & 5 & 1 & 2 & 3 & 4 & 5 \\
\hline - Ability of logical and convincing argumentation & 1 & 2 & 3 & 4 & 5 & 1 & 2 & 3 & 4 & 5 \\
\hline - Ability to put through his/her opinion and a good solution & 1 & 2 & 3 & 4 & 5 & 1 & 2 & 3 & 4 & 5 \\
\hline - Appropriately self-aware and assertive & 1 & 2 & 3 & 4 & 5 & 1 & 2 & 3 & 4 & 5 \\
\hline
\end{tabular}




\begin{tabular}{|l|l|l|l|l|l|l|l|l|l|l|}
\hline Evaluation criteria & \multicolumn{3}{|c|}{ Profile } & \multicolumn{5}{|c|}{ Evaluation } \\
\hline 9. Ability to learn, open to change & \multicolumn{3}{|c|}{} & \multicolumn{5}{|l|}{$\mid$} \\
\hline - Ability to learn from own and alien faults & 1 & 2 & 3 & 4 & 5 & 1 & 2 & 3 & 4 & 5 \\
\hline - Constantly searching for self-development opportunities & 1 & 2 & 3 & 4 & 5 & 1 & 2 & 3 & 4 & 5 \\
\hline - Handling changes within a short, medium, and long perspective & 1 & 2 & 3 & 4 & 5 & 1 & 2 & 3 & 4 & 5 \\
\hline - Bearer of new ideas for solutions & 1 & 2 & 3 & 4 & 5 & 1 & 2 & 3 & 4 & 5 \\
\hline - Ability to apply novelties in the field in his/her work & 1 & 2 & 3 & 4 & 5 & 1 & 2 & 3 & 4 & 5 \\
\hline
\end{tabular}

Legenda:

\begin{tabular}{|l|l|}
\hline & Minimal profile \\
\hline \hline & Optimal profile \\
\hline & Actual profile \\
\hline
\end{tabular}

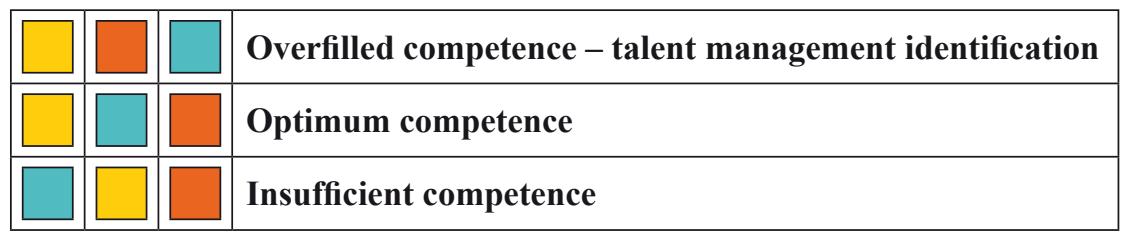

IV: Behavioural scale of competences

\begin{tabular}{|c|c|c|c|c|}
\hline \multicolumn{5}{|c|}{ Evaluated competence } \\
\hline \multicolumn{5}{|l|}{ INITIATIVE* } \\
\hline 1 & 2 & 3 & 4 & 5 \\
\hline \multicolumn{5}{|c|}{ - Bringing proposals and solutions independently } \\
\hline $\begin{array}{l}\text { Does not bring } \\
\text { in proposals or } \\
\text { solutions as a } \\
\text { person or team } \\
\text { member, either }\end{array}$ & $\begin{array}{l}\text { Offering proposals } \\
\text { and solutions as } \\
\text { team member } \\
\text { only, not assertive } \\
\text { in the team, } \\
\text { his/her individual } \\
\text { proposals and } \\
\text { solutions are scarce }\end{array}$ & $\begin{array}{l}\text { Suggests drafts and } \\
\text { solutions in the } \\
\text { team and is able to } \\
\text { put them through } \\
\text { in an average way. } \\
\text { Without team } \\
\text { participation hardly } \\
\text { any initiative. }\end{array}$ & $\begin{array}{l}\text { Suggests drafts and } \\
\text { solutions in the } \\
\text { team and is able to } \\
\text { put them through } \\
\text { with team support; } \\
\text { as an individual } \\
\text { in an average way } \\
\text { only. }\end{array}$ & $\begin{array}{l}\text { Submitting new } \\
\text { proposals and } \\
\text { feasible solutions } \\
\text { independently, } \\
\text { able to put through } \\
\text { the solutions in } \\
\text { the team, has } \\
\text { arguments as an } \\
\text { individual, able to } \\
\text { pull others into a } \\
\text { problem }\end{array}$ \\
\hline \multicolumn{5}{|c|}{ - Overcoming of problems } \\
\hline $\begin{array}{l}\text { Unable to } \\
\text { overcome } \\
\text { difficulties, } \\
\text { unconditionally in } \\
\text { need of help from } \\
\text { the others }\end{array}$ & $\begin{array}{l}\text { Can partially } \\
\text { overcome } \\
\text { difficulties, simple } \\
\text { situations, needs } \\
\text { assistance in case } \\
\text { of complex ones }\end{array}$ & $\begin{array}{l}\text { Can overcome } \\
\text { simple and } \\
\text { more complex } \\
\text { situations, tends } \\
\text { to make errors in } \\
\text { the procedure and } \\
\text { usually needs some } \\
\text { help } \\
\end{array}$ & $\begin{array}{l}\text { Able to handle } \\
\text { difficulties rather } \\
\text { independently, } \\
\text { sometimes in a } \\
\text { wrong way, needs } \\
\text { help now and then }\end{array}$ & $\begin{array}{l}\text { Solves difficulties } \\
\text { alone, as a rule, } \\
\text { achieving the } \\
\text { correct solution } \\
\text { without the } \\
\text { assistance of third } \\
\text { parties }\end{array}$ \\
\hline \multicolumn{5}{|c|}{ - Looking for new opportunities and possibilities } \\
\hline $\begin{array}{l}\text { Unable to find } \\
\text { new opportunities, } \\
\text { works with the } \\
\text { available stuff }\end{array}$ & $\begin{array}{l}\text { Limited search for } \\
\text { new opportunities; } \\
\text { he/she may see } \\
\text { them, yet without } \\
\text { working with them }\end{array}$ & $\begin{array}{l}\text { Looks for new } \\
\text { opportunities in } \\
\text { the average, works } \\
\text { with them with } \\
\text { average success }\end{array}$ & $\begin{array}{l}\text { Can see and } \\
\text { look for new } \\
\text { opportunities, } \\
\text { works with them } \\
\text { intensively with } \\
\text { better than average } \\
\text { success }\end{array}$ & $\begin{array}{l}\text { Has prerequisites } \\
\text { for finding new } \\
\text { opportunities } \\
\text { and possibilities, } \\
\text { looks for them } \\
\text { intensively while } \\
\text { using them with } \\
\text { excellent success }\end{array}$ \\
\hline
\end{tabular}




\begin{tabular}{|c|c|c|c|c|}
\hline \multicolumn{5}{|c|}{ Evaluated competence } \\
\hline \multicolumn{5}{|l|}{ INITIATIVE $^{\star}$} \\
\hline 1 & 2 & 3 & 4 & 5 \\
\hline \multicolumn{5}{|c|}{ - Responsible for his/her own work } \\
\hline $\begin{array}{l}\text { Not interested in } \\
\text { the result and the } \\
\text { quality of his/her } \\
\text { own work }\end{array}$ & $\begin{array}{l}\mathrm{He} / \text { she may fulfil } \\
\text { his/her work, but } \\
\text { to the detriment of } \\
\text { quality; control is } \\
\text { necessary }\end{array}$ & $\begin{array}{l}\text { Responsible for } \\
\text { his/her work, } \\
\text { usually in average } \\
\text { quality, inspection } \\
\text { is needed now and } \\
\text { then }\end{array}$ & $\begin{array}{l}\text { Responsible for his/ } \\
\text { her work, focussing } \\
\text { upon quality, an } \\
\text { achievement with } \\
\text { minor deficiencies, } \\
\text { practically without } \\
\text { inspection }\end{array}$ & $\begin{array}{l}\text { Performs his/her } \\
\text { work in high } \\
\text { quality, responsibly } \\
\text { as to delays, no } \\
\text { checking is needed, } \\
\text { he/she sees the } \\
\text { quality of work as } \\
\text { priority }\end{array}$ \\
\hline \multicolumn{5}{|c|}{ - Applying appropriate risk } \\
\hline $\begin{array}{l}\text { Risk is alien to } \\
\text { him/her, he/she } \\
\text { does not risk for } \\
\text { any price and is } \\
\text { afraid of risk. Or: } \\
\text { Behaves very risky } \\
\text { even if there is no } \\
\text { necessity, and even } \\
\text { high probability of } \\
\text { loss. }\end{array}$ & $\begin{array}{l}\text { Perceives risk and } \\
\text { slightly adapts his/ } \\
\text { her decisions to it. }\end{array}$ & $\begin{array}{l}\text { Perceives risk. But } \\
\text { he/she behaves } \\
\text { too conservatively } \\
\text { or, the other way } \\
\text { round, risks too } \\
\text { much. }\end{array}$ & $\begin{array}{l}\mathrm{He} / \text { she perceives } \\
\text { risk and works } \\
\text { with it, is slightly } \\
\text { conservative or } \\
\text { sometimes takes a } \\
\text { risk. }\end{array}$ & $\begin{array}{l}\text { Depending on } \\
\text { situation he/she } \\
\text { evaluates the } \\
\text { aspects of risk } \\
\text { and chooses } \\
\text { accordingly a } \\
\text { solution and } \\
\text { diversifies his/her } \\
\text { decision. }\end{array}$ \\
\hline
\end{tabular}

* Note: This is the example of behavioural scale of just one competence.

Education and development of employees is a field requiring quite considerable corporate resources. As to talent management, however, we talk about a different, and a very specific issue. Talented employees do not exceed $5 \%$ of all employees of the company in the average. If comparing the resources invested by the company into the development of talents with the fact that a talented employee represents an investment into the bearers of corporate know-how, I am confident that an investment of this type will certainly pay off. This is, namely, an investment into the company by personnel with fast return on investment.

\section{CONCLUSION}

Globalisation is a prevailing trend influencing the present day labour markets. Various countries of the
European Union, but also other developed countries often repeat the concept „brain-drain“. The openness of economy and broad choice out of many opportunities inspire talented people to implement their career abroad. Foreign companies often focus upon acquiring top professionals from the whole world, as they expect them to offer also a high degree of flexibility and adaptability, which they usually need. These characteristics of the labour market should be taken into account by all companies wishing to successfully cope with global competition in the long-term. The companies must apply their efforts, and also financial means in order to identify the ways and create preconditions for the development of young and talented personnel who are likely to become corporate knowhow bearers in the future.

\section{SOUHRN}

\section{Vzdělávání a rozvoj talentů}

Příspěvek popisuje metodiku rozvoje a vzdělávání talentů v mezinárodní společnosti - talent management. Cílem talent managementu je identifikovat a vytvořit prostor pro rozvoj a následné vzdělávání zaměstnanců s vysokým, nadprůměrným potenciálem, kteří mohou být nositeli konkurenční výhody společnosti. Práce představuje metodický aparát pro implementaci systému talent managementu v následujících oblastech: definování talentu, identifikace talentů, vytvoření podmínek, péče ze strany managementu, individuální či skupinové odborném vzdělávání, rozvoj schopností, dovedností a hodnocení výsledků jak v oblasti schopností a dovedností jednotlivce prostřednictvím klíčových kompetencí, 
tak prostřednictvím ukazatelů pracovního výkonu. Popisuje rámcově hodnocení prostřednictvím klíčových kompetencí - minimální, optimální a aktuální profil kompetenční profil a jednotlivé kompetence, jejichž projevy jsou popsány behaviorálními škálami. Př́spěvek je součástí výzkumného grantu MSM 6215648904.

vzdělávání, rozvoj, talent, talent management, klíčové kompetence, hodnocení

\section{REFERENCES}

ARMSTRONG, M.: Ǩizení lidských zdrojů. 1. vyd. Praha: Grada Publishing, 2002. 856 s. ISBN 80247-0469-2.

BONTIS, N., DRAGONETTI, N. C., JACONSEN, K., ROOS, G.: The knowledge toolbox: A review of the tool available to measure and manage intangible resources. European Management Journal, 1999, roč. 17 , č. 4 , s. 391- 402 .

HRONÍK, F.: Poznejte své zaměstnance: vše o Asse- ssment Centre. 1. vyd. Brno: ERA, 2002. 370 s. ISBN 80-86517-20-9.

KUBEŠ, M., SPILLEROVÁ, D., KURNICKÝ, R.: Manažerské kompetence: zpưsobilosti výjimečných manažerì. 1. vyd. Praha: Grada Publishing, 2004. 184 s. ISBN 80-247-0698-9.

PLAMÍNEK, J., FIŠER, R.: Řizení podle kompetencí. 1. vyd. Praha: Grada Publishing, 2005. 180 s. ISBN 80-247-1074-9.

SMITH, A.: The Wealth of Nations. Edinburgh: John Murray, 1776. 
